\title{
Nuevos poemas exhumados de Ramón Pérez de Ayala
}

\author{
JosÉ TOMÁS CAÑAS JIMÉNEZ \\ Universidad Complutense
}

Este trabajo está dedicado a la presentación de tres poemas olvidados de don Ramón Pérez de Ayala: La mandolinata (1903), La diosa locura (1903), y La bella Lucerito (1911). Tres nuevas aportaciones que engrosarán la que esperamos, algún día, poder llamar obra completa del creador asturiano. Y que para intentar llegar a dicho momento resta trabajar, sobre todo, la faceta menos investigada de nuestro gran autor: las publicaciones periódicas.

Pérez de Ayala comenzó muy tempranamente su colaboración en distintos medios escritos de su ciudad natal; según Angeles Prado «inicia su vida periodística en Oviedo escribiendo revistas de las riñas de gallos, a las que asistía con su padre. Estos artículos, que iban en prosa y en verso, aparecieron en $E l$ correo de Asturias bajo el nombre de Torquemada» ${ }^{1}$. Jesús Andrés Solís nos confirma en otra información, que «existía por entonces en Oviedo un periódico que se publicaba dos veces por semana. Se había fundado en el año 1883, titulado El porvenir de Asturias... El trabajo titulado El milagro del padre Padial y una novela corta que tituló Trece Dioses, publicados en este periódico, fueron los primeros pasos dados en firme en el campo de las letras...." ${ }^{2}$; en cambio Lozano Marco, refiriéndose a la obrita Trece

1. Prado, A., «Seudónimos tempranos de Pérez de Ayala», en Insula, núms. 404-5, julioagosto 1980 , pp. 1 y 18.

2. Solís, J.A., Vida de Ramón Pérez de Ayala, Imprenta El Faro-Candás, 1979, p. 30. 
Dioses, rectifica la publicación periodística donde está ubicada y nos declara que "sabemos hoy, con toda certeza, que esa primera novela corta no vio la luz en el periódico citado, sino en El progreso de Asturias, diario republicano nacido en Oviedo en 1901 y de breve existencia (hasta 1905)»3.

Mas estos primeros escarceos todavía no han sido publicados; y aquellos que versan sobre peleas de gallos, que con seguridad han de ser anteriores a 1900, tampoco hemos podido verlos (todo se andará). Por tanto debemos -de momento- ceñirnos, respecto a sus primeras colaboraciones, a aquellas revistas y periódicos que, a su llegada a Madrid, le ofrecieron sus páginas para estampar sus ideas y frescos conocimientos. Una vez instalado en Madrid ${ }^{4}$, revistas como Alma española, La revista ibérica, La lectura, Helios... ${ }^{5}$ plasmaron su firma; y periódicos, destacando su colaboración en $E$ l imparcial ${ }^{6}$ dirigido por Ortega y Munilla, padre de su gran amigo José Ortega y Gasset. Es el comienzo de lo que se puede llamar una duradera relación intelectual y de información con el público, cuyo mediador fue la prensa escrita. Al respecto señala Fernández Avello que «la trayectoria vital del escritor Pérez de Ayala se halla vinculada a los periódicos, a la servidumbre de la colaboración en las revistas" ${ }^{7}$. Si bien es incuestionable que nuestro autor mantuvo una relación simbiótica con la prensa a causa de imperiosas necesidades económicas que le atribularon la mayor parte de su vida, no es cierto que el inicio de esta su relación con las publicaciones periódicas esté marcado por el mismo signo, muy al contrario, el joven Ayala, recien llegado a Madrid, necesita publicar aquello que, bien trae confeccionado en su maleta, bien porta en su mente despejada y clarividente, con el indeleble fin de adquirir fama ante el público y los editores, y sirva para ello la noticia

3. Lozano Marco, M.A., Del relato modernista a la novela poemática: la narrativa breve de Ramón Pérez de Ayala. Universidad de Alicante. C.A.P., Alicante, 1983, p. 22.

4. Según nos apunta J.A. Solís en su biografía sobre el autor, éste llegó a Madrid «a principios del otoño del año 1901 (p. 37).

5. Su primer trabajo en Alma española fue: "Panteísmo asturiano», 20.02.1902. En La revista ibérica, ver Macklin, J.J.: "Ramón Pérez de Ayala y La revista ibérica» en BIEA, n. ${ }^{\circ} 107$; sep.-oct. 1982, pp. 683-689. En La lectura: "Emilio Verhaeren", septiembre 1902. En Helios: "La aldea lejana, con motivo de la aldea perdida", abril 1903.

6. El primer trabajo que publicó es una narración corta titulada "Quería morir", 01.02.1904.

7. Fernández Avello, M., "Ramón Pérez de Ayala y el periodismo", en Gaceta de la prensa, en-feb., 1961, pp. 6-7. 
contenida en una de las cartas escritas a su amigo Miguel RodríguezAcosta, fechada el 27 de octubre de 1904, donde le comenta:

Como es natural, me encuentro en perfecta tranquilidad de espíritu... Espero hacer acopio de energías y ponerme pronto a trabajar, no con noble ahínco y desinteresado fin de arte, sino en coña y buscando por todos los medios lícitos o ilícitos estéticamente el halago fácil de esas malas bestias -los editores y directores de periódicos- y ese animal inmundo-el público- ${ }^{8}$.

Muy distinta se presenta la vida del joven Ayala con posterioridad al fatídico fallecimiento de su padre-febrero 1908-. Ahora sí necesitará de la colaboraciones periodísticas para poder desempeñar con decoro económico el ejercicio literario, como demuestra una carta -con fecha 23.09.1910- dirigida al "venerable y amado maestro", que así era su tratamiento hacia don Benito Pérez Galdós:

Necesito que Vd. escriba a D. Miguel Moya ${ }^{9}$ algunas líneas en favor mio: quiero comenzar... a hacer impresiones críticas... Se lo suplico a $\mathrm{Vd}$. con particular instancia porque mi situación económica es muy apurada ${ }^{10}$.

Deducimos dos etapas en la trayectoria de colaborador periodístico de don Ramón: a) Primeros trabajos en publicaciones de su ciudad natal. Llegada a Madrid e iniciales contactos; búsqueda de la fama y despreocupación económica; b) Desde la muerte de su padre hasta, casi, los últimos momentos. Imperiosa necesidad de colaborar para con ello subsanar su tan mal traída economía, puesto que la publicación de nuevas obras y la reedición de otras no reportaban suficientes emolumentos.

Pérez de Ayala, en su dilatada carrera de colaboración en diferentes medios de letra impresa, publicó -mayoritariamente- artículos, de diversa índole temática, todos impregnados de ese tan peculiar estilo que le caracterizaba, además de ser portadores de la formidable cultura que su ejecutor poseía; y textos estrictamente literarios: cuentos y poemas. A estos últimos me referiré posteriormente. Antes un inciso, y mencionar la teoría de Pierre Sallenave con res-

8. Pérez de Ayala, R., Cincuenta años de cartas intimas, 1904-1956, a su amigo Miguel Rodríguez-Acosta, edición y prólogo de A. Amorós, edit. Castalia, Madrid, 1980, p. 44.

9. Miguel Moya era, en ese momento, director del diario El liberal.

10. Schraibman, J., "Cartas inéditas de Pérez de Ayala a Galdós», en Hispanófila, n. ${ }^{\circ} 17$, 1963, pp. 83-103. 
pecto a la importancia de los ensayos -que no artículos-periodísticos de nuestro autor: «...se conoce a Pérez de Ayala por sus novelas y su poesía, pero, en realidad, Pérez de Ayala es un ensayista" ".

No es muy convincente tal teoría, ni aquella que defienda otra parcela genérica, en concreto, del escritor asturiano. Creo, ante todo, que Pérez de Ayala es un "creador", y que como una totalidad de pensamiento y humanismo, y sólo como tal, se entenderá su obra completa, cuando se estudien los grandes vínculos existentes en la estructura profunda de los géneros por él practicados. La comprensión y entendimiento del pensamiento y teoría de don Ramón Pérez de Ayala será el resultado de la investigación conjunta de su total producción literaria.

Aunque cuantitativamente representan una minoría con respecto a sus artículos-ensayos, las publicaciones periodísticas de cuentos y poesías son de un enorme valor: En relación a la cuentistica poseemos hoy en día, un pormenorizado y exhaustivo estudio de Miguel Angel Lozano Marco ${ }^{12}$ donde clasifica e investiga el contenido y forma del texto para su mayor comprensión. Mas falta el riguroso estudio que obtendríamos si tuviésemos todas las versiones (en este caso periodísticas) de cada uno de los textos; trabajo que se realiza con otros autores y del que nuestro insigne autor hállase abandonado -objetivo impuesto y en el que estoy trabajando-. Sirvan de ejemplo, para demostrar la importancia del mencionado trabajo, los datos que a continuación expongo. El relato El último vástago, hasta el momento, puede estudiarse manejando dos versiones: a) el manuscrito del texto que es del que se sirvió García Mercadal para introducirlo en la segunda edición del tomo I de las Obras Completas ${ }^{13}$; b) una versión hallada por Joaquín Forradellas ${ }^{14}$ en la revista barcelonesa Hojas selectas (junio-septiembre de 1905, el texto abarca las páginas 535-542, 626-632, 721-727, 825-832, 921-928 y 1015-1022); y una tercera versión -en este caso segunda periodística- que doy a conocer, ahora, en

11. Sallenave, P., "La estética y el esencial ensayismo de Ramón Pérez de Ayala», en Cuadernos Hispanoamericanos, n. ${ }^{\circ} 234$, junio, 1969, p. 601.

12. Lozano Marco, M.A.: Vide cita 3.

13. Pérez de Ayala, R., El último vástago en Obras Completas I, 2. edición Aguilar, Madrid, 1973, pp. 11-83.

14. Forradellas, J., "El último vástago: novela primera de Pérez de Ayala" en Letras de Deusto, vol. 5, n. $^{\circ}$, enero-junio de 1975, pp. 137-155. 
estas páginas, y que fue publicada en el diario La prensa de Buenos Aires en doce entregas, los días 21, 22, 23, 24, 25, 26, 27, 28, 29, 30 y 31 de octubre y el 1 de noviembre del año $1916^{15}$ once años después de su primera aparición.

Otro caso, hasta hoy desconocido, nos lo ofrece el cuento La prueba, escrito, según aparece en la tabla cronológica realizada por Lozano Marco (Del relato modernista..., 1983; p. 39), en el año 1905; que aparece en la segunda edición del tomo I de las Obras completas, p. 1100 , con el día y el mes -24 de junio- de su escritura o publicación; y escribo publicación porque efectivamente la fecha -24.06.1905- se corresponde con la datación que poseo del texto, tras haberlo hallado publicado en la revista Blanco y negro, con la misma fecha de 24.06.1905. Pues bien, de este mismo texto he encontrado una nueva versión, que es de gran interés, publicada en la revista madrileña La semana, en el número 23 , correspondiente al día 21.10.1916, páginas 6 y 7 . Es inconcuso que un trabajo realizado con estas garantías, manejando siempre que sea posible la mayoría de versiones existentes o la totalidad de ellas, dará como resultado un positivo fruto a nuestra investigación.

Análoga situación tenemos con la poesía. El único estudio serio, sobre la poesía de nuestro autor es el realizado por Víctor García de la Concha ${ }^{16}$; contiene un análisis profuso de las fuentes, acercamiento al texto, evolución de la poética ayalina y algo que se debe destacar: la confección de una tabla cronológica de los poemas. Aunque, eso sí, en numerosos casos se desconoce la primera publicación de esos textos, por lo que el estudio adolece de un verdadero análisis crítico de las variantes. Algo similar defiende Elías García Domínguez refiriéndose al trabajo de García de la Concha a propósito de las. variantes existentes entre el texto de Obras completas y el de las primeras ediciones. García Domínguez cree que «una confrontación cuidadosa habrá de dar, sin duda, una cosecha nutridísima, a juzgar

15. Gregor O’Brien en su estudio (Tesis Doctoral) El ideal clásico de Ramón Pérez de Ayala en sus ensayos en "La prensa" de Buenos Aires, pasa por alto esta publicación, la cual le ha pasado desapercibida en su trabajo recolector de los artículos-ensayos de don Ramón en dicho diario. No siendo el único caso.

16. García de la Concha, V., Los senderos poéticos de Ramón Pérez de Ayala en Archivum, XX, Oviedo, 1970. 
por las variantes que se pueden apreciar en los textos en prosa hasta ahora estudiados»" 17 .

Efectivamente estas variantes se dan en los poemas de Pérez de Ayala; veamos algunos casos:

a) El poema Dame mi premio que forma parte de la novela Troteras y danzaderas, se publicó por vez primera el 03.04.1911 en Los lunes de "El imparcial»" ${ }^{18}$. Este presenta diversas variantes entre las tres versiones que he cotejado: El imparcial, Troteras y danzaderas ${ }^{19}$, Obras completas ${ }^{20}$. En principio advertir que, tras la comparación efectuada, la noticia ofrecida por García Domínguez en su trabajo, y que dice: «El texto de Dame mi premio (O.C., 55-56) se aparta también del poema correspondiente publicado en Troteras y danzaderas (O.C., 561-562) en no menos de ocho versos» ${ }^{21}$, no puedo ratificarla porque tras su comprobación resulta que varían en un verso. Me explico. Los textos de El imparcial y el de O.C. II, p. 55-56, ofrecen el siguiente texto:

«dame la paz que he conocido!

Aleja

de mis labios el pámpano en agraz» (versos 13,14,15)

Mientras que en Troteras y danzaderas (tanto en O.C.I, 1. ${ }^{\mathrm{a}}$ edición, 1963; pp. 561-562, como en la edición de Andrés Amorós, Castalia, 1984) los versos se distribuyen así:

«dame la paz que he merecido. Aleja

de mis labios el pámpano en agraz" (versos 13,14)

Esta es la verdadera diferencia entre los textos que he compro-

17. García Domínguez, E., "Sobre la poesía de Pérez de Ayala», en BIEA, n. 73 , vol. xxv, Oviedo, 1971, p. 389.

18. Estos datos, completos, los ofrezco en primicia; hasta ahora eran desconocidos. García Domínguez (ver nota 17, p. 387), advirtiendo el error cronológico de García de la Concha -lo fecha en 1913-, rectifica y declara la fecha que consta en O.C. II (p. 56): 13.04.1911; siendo, por lo que respecta al día, erróneo; además de no constar la publicación donde aparece.

19. Pérez de Ayala, R., Troteras y danzaderas, edición de A. Amorós. Castalia, Madrid, 1984, pp. 146-147.

20. Pérez de Ayala, R., Obras Completas II, Aguilar, Madrid, 1963, pp. 55-56.

21. García Domínguez: Ibid, p. 390. 
bado. A continuación expongo algunas - no todas- variantes de estos textos:

El imparcial

O.C. II

Troteras y danzaderas

V.4: "y he bebido de mi vino agrio y

V.4: «y he bebido mi vino acedo...» acedo;..."

V.6: "...y crímenés confusos del antaño..." V.6: "...delitos arrastrados del antaño..."

V.26: «...un albergue, no más, de rústica esquiveza..."

V.25: «una casa no más, de aldeana esquiveza...»

El imparcial

Troteras y danzaderas

O.C. II

V.1: «Señor: yo que he sufrido tanto, tanto»

V.1: «Señor: yo he sufrido tanto, tanto"

V.23: «...que allí nuestra oración»

V.23: «...que allí nuestra canción»

b) El poema Figuras elegíacas se publicó el 21.11.1910 en Los lunes de "El imparcial»" ${ }^{22}$, y corresponde al texto que comienza con el verso Cerrar los ojos... que aparece en la tabla cronológica ofrecida por García de la Concha en su trabajo ${ }^{23}$, aunque en éste se fecha, junto con el resto de los poemas de La pata de la raposa, en el año 1911.

Cotejadas distintas versiones del poema -El imparcial, Obras completas $^{24}$, La pata de la raposa ${ }^{25}$ - he observado, así mismo, ciertas variantes en el número de versos ${ }^{26}$ y en el léxico utilizado. El texto de El imparcial y el de O.C. II (pp. 62-63) poseen el mismo número de versos: veinticuatro; difiere del texto de

22. Sin caer en pedantería, no me queda otro remedio que decir que también la fechación completa de este poema aparece por vez primera en estas páginas.

23. García de la Concha, V., Ibid, p. 26.

24. Pérez de Ayala, R., Ibid, pp. 62-63.

25. Pérez de Ayala, R., La pata de la raposa, editorial Renacimiento s.a., Madrid, pp. 313-314.

26. García Domínguez, E., Ibid, p. 390, constata también la diferencia cuantitativa de versos, aunque sin manejar las mismas versiones que yo. 
La pata de la raposa el cual posee veinte. A éste le faltan los cuatro últimos que constan en las otras dos versiones:

Luego, el éxtasis de vivir.

Luego, sentir un eternal sentido,

-pretérito, presente, por venir-

y dar gracias a Dios de haber nacido.

El texto de O.C. II (pp. 62-63) es idéntico al aparecido en El imparcial -primera versión periodística del poema-por lo que no cabe duda que García Mercadal se sirvió de una copia manuscrita de éste para fijar su contenido en las O.C. II.

Variantes léxicas:

El imparcial

O.C. II
La pata de la raposa
V.2: «...ciega, sagaz y cauta, asirte...»

V.3: «...las tuyas, breves...»

V.8: «...de joven pulcritud...»
V.2: "-aunque ciega, sagaz y cauta asirte..."

V.3: "...la tuya breve..."

V.8: «...de infantil pulcritud...»

Y por último, respecto a este texto, señalar que en la primera edición de La pata de la raposa el verso séptimo aparece como sigue: "tu aroma sin aroma, que dimana", mientras en la excelente edición realizada por el profesor Andrés Amorós (La pata de la raposa, Labor, 1970) este verso queda de la siguiente forma: «tu aroma, que dimana».

c) La danza universal se publicó el 26:04.1915 -asimismo-en Los lunes de "El imparcial ${ }^{27}$, y posteriormente sería incorporado al libro de poemas $E l$ sendero andante ${ }^{28}$. Además de las versiones de El imparcial y la primera edición de El sendero andante, he utilizado la edición de éste en Obras completas $I I$ (1963); a partir de ahora citaré por el año de la edición, según corresponda: 1915, 1921, 1963.

En la versión de 1915 el poema consta de sesenta y nueve versos, mientras que las de 1921 y 1963 están formadas por tres

27. También estos datos, en primicia, son de mi cosecha.

28. Pérez de Ayala, R., El sendero andante: Momentos. Modos. Ditirambos. Doctrinal de vida y naturaleza. Edit. de «Saturnino Calleja», s.a., Madrid, MXMXXI, pp. 79-85. 
versos más -es decir, setenta y dos-, y son los pertenecientes al terceto cuyos versos corresponden a los números 59,60 y 61 de estas dos últimas versiones:

Por el palo el oso y el can, por el pan el pelafustán, por la venera el chambelán.

Este texto presenta menos variantes, pero es relevante que algunas de ellas difieran en las tres versiones. Veámoslas:

1915:

V.2: "y fabulosa-mirra y sol-;"

V.65: "y es superfluo añadir qué tal»

1921:

V.2: «y fabulosa -mirra y sal-;"

v.68: «yo no digo si bien o mal»

1963:

V.2: «y fabulosa -sol y sal-;»

V.68: «sólo Él sabe si bien o mal»

Ha sido empeño demostrativo el ejemplificar con estos casos minoritarios parte de la abundante colaboración de Pérez de Ayala en la prensa escrita, en su activa vida profesional. $Y$ ratificar la necesidad de estudiar esta parcela tan olvidada en el escritor asturiano; pues, aunque meritorio, es insuficiente lo llevado a cabo por el erudito José García Mercadal. Primero, porque son muchos los artículos que restan por recuperar; segundo, porque no existe una investigación crítica que abarque la ensayística ayalina ${ }^{29}$. Además de lo yà consignado sobre su narrativa corta y poesía.

Ramón Pérez de Ayala accedió a la consagración en el agreste mundo literario mediante la publicación de un libro de poemas titulado La paz del sendero en $1904^{30}$. La poesía es el género en el que se inicia con ahínco y predilección, y del que se acompañará en los últimos días de su existencia. Ya desde el inicio de su labor creadora, con el libro señalado, se vislumbran en esencia las características

29. Si exceptuamos el trabajo de O'Brien -Ibid, nota 15- y algunos artículos en diferentes publicaciones, este campo está por abonar todavía.

30. En fechas anteriores había publicado una novela corta titulada Una aventura del padre Francisco en el n. ${ }^{\circ} 3$ de Helios, junio 1903; y Trece dioses, además de artículos tempranos, diversidad de cuentos y poemas en publicaciones periódicas. 
poéticas y prosaicas que en el futuro, ya maduradas, propiciarán un estilo intelectualmente tan rico y original; condensando, como él mismo advierte en todo escritor, «dos factores...: la tradición y la época» ${ }^{31}$. Además del título mencionado, publicó dos libros más de poemas: El sendero innumerable-1916-, y El sendero andante-1921-32.

La teoría omnicomprensiva y universal sobre la poesía nos la expresa el creador asturiano en los siguientes términos: "La poesía... se reduce a una visión íntegra de la vida ${ }^{33}$; pero, además se refiere a una reflexión individualizada subjetiva, la cual, solidarizándose, se convierte en algo superior y colectivo; como el mismo autor nos comunica, "el semblante auténtico del alma de cada pueblo se retrata en su poesía» ${ }^{34}$.

Desde los primeros inicios don Ramón fue excelentemente considerado por la crítica, tanto militante como académica, que no vio en él esterilidad de contenidos ni ornamentación excesiva en lo formal. Así, Pedro González Blanco nos advirtió que «y bien superficial será quien vea en él un retórico decadente, inclinado a los concetti, por esa su distinción, correcta y encerrada en el ideal clásico del estilo ${ }^{35}$. Y este su estilo no es reflejo de superficialidad, mas al contrario, es un conjunto de excelencias personalísimas reflejadas en su poética, al ser el joven autor asturiano, como advierte el anterior crítico, "uno de los pocos jóvenes que tienen en España la enfermedad de la perfección y la cultura suficiente para tenerla» ${ }^{36}$. Y refiriéndose, en concreto, a La paz del sendero, considera la poesía contenida en él como «lenta y enervadora evocación de espectáculos en claro obs-

31. Pérez de Ayala, R., Divagaciones literarias, Biblioteca Nueva, Madrid, 1958, p. 214.

32. La poesía de Pérez de Ayala se vio incrementada cuantitativamente en la edición de las Obras completas, tomo II realizada por el erudito José García Mercadal, en dos títulos: los mal llamados Primeros frutos (por la cronología muchos de estos poemas distan de adscribirse a tal título); y El sendero ardiente, obra no finalizada por el autor debido a las alteraciones emocionales que don Ramón hubo de afrontar en sus últimos años. Ayala en el Alegato "pro domo mea" de la edición de Poesías completas, Buenos Aires, 1942, manifiesta faltarle dos poemas: "el del fuego y el del airem.

33. Pérez de Ayala, R., Obras completas, tomo III, Aguilar, Madrid, 1963, p. 157.

34. Ibid, p. 158.

35. González Blanco, Pedro, «Ramón Pérez de Ayala. La paz del sendero» en Nuestro tiempo, abril-mayo de 1904, p. 271.

36. González Blanco, Pedro, Ibid, p. 271. 
curo por la sabia yuxtaposición de imágenes, por asociaciones de ideas y de palabras imprevistas»" ${ }^{37}$.

Angel Guerra es más tajante y sagaz, llega a declarar que «La paz del sendero, libro de poeta, me reconcilia un tanto con la lírica española moderna" ${ }^{38}$, y ello es debido a que "pocos como él saben y pueden sentir el alma de las cosas” ${ }^{39}$, puesto que, en opinión del crítico, en la poesía española respíranse aires poço favorables:

La lírica se halla en plena crisis, por no decir irremediable decaden$\operatorname{cia}^{40}$.

Y es en Pérez de Ayala donde encuentra el crudo sabor de lo terreno y el alto vuelo del espíritu, y por ello advierte dos orientaciones definidas en nuestro creador:

De pronto remóntase idealista, con aliento místico... mientras que en otras ocasiones, arraiga en la tierra con marcado sabor panteísta, y a los seres inanimados les da alma y vida ${ }^{41}$.

Crítico inteligente e inmenso poeta, Rubén Dááo expresó en breves y precisas palabras sus primeras impresiones sobre un joven poeta que había dado a la luz su primer libro La paz del sendero; tras la lectura de la obra manifiesta Darío que «tiene el autor demasiado talento para que sonriamos ante la premura de un dolor fatal apenas entrevisto. Desde esos primaverales años clama una voz de hondo y meditabundo poeta, animado por el mismo saber, amargo don del destino $"^{42}$. Y subraya algo que será característica inconcusa e indeleble a lo largo de su vida como creador y estilista, acaparando no menos adversidades de lectura ante el gran público que ante la crítica: su intelectualismo estructural y racional. Comenta el maestro, sobre el futuro gran maestro:

Pérez de Ayala, de abolengo literario que obliga, es, en la generación a que pertenece, de los poetas que piensan ${ }^{43}$.

37. González Blanco, Pedro, Ibid, p. 269.

38. Guerra, Angel, "La paz del sendero, por Ramón Pérez de Ayala», en La lectura, octubre 1904, p. 175.

39. Guerra, Angel, Ibid, p. 176.

40. Guerra, Angel, Ibid, p. 175.

41. Guerra, Angel, Ibid, p. 177.

42. Pérez de Ayala, Ramón, Obras completas, tomo II, Aguilar, Madrid, 1963, p. 72.

43. Ibid, p. 72 . 


\section{Los poemas olvidados}

Me refiero a La mandolinata -07.02.1903-; La diosa locura -22.02.1903-, ambos publicados en la revista El álbum Iberoamericano; y La bella Lucerito, aparecido en enero de 1911 en la publicación Comedias y comediantes; las dos, revistas madrileñas.

El álbum Ibero-americano, de aparición quincenal, es una revista de formato grande, ilustrada en blanco y negro. El director era Francisco de Paula Flaquer. El contenido era muy diverso, aunque predominaba el carácter aleccionador y didáctico; así, se encuentran análisis sobre temas sociales, arte, publicación de cuentos y poesías de jóvenes autores, y otras secciones variadas de gran actualidad en su momento. Sobresale la dirigida por Concepción Gimeno de Flaquer, de marcado signo feminista, con artículos como el titulado ¿Mujer $o$ hembra?; colaboraron también en esta sección Carolina Coronado y Carmen de Burgos Seguí (Colombine). En el terreno crítico-artístico nombres como el de Rubén Darío - La gitanilla, poema, 22.08.1903-, Enrique Díez-Canedo, Pedro de Répide, Eugenio Sellés, Pedro González Blanco, José Nogales, Maurice Leblanc, Maeterlink, D’Annunzio, Eça de Queiroz, y el ensayo del eminente Premio Nobel de medicina -además de gran humanista- Ramón y Cajal: Sobre el Quijote, 07.03.1903.

Comedias y comediantes se publicó desde el año 1909 hasta 1912; desde el n..$^{1}$-01.11.1909- hasta el n. ${ }^{\circ} 23$, octubre de 1910, su aparición fue quincenal; y desde el n. ${ }^{\circ} 24$, octubre de 1910 , hasta el n. ${ }^{\circ} 43$, mayo de 1912, mensual. El contenido, como nos sugiere el título de la misma, versa sobre el mundo del teatro: entrevistas a los actores, actrices y autores del momento; crónicas de importantísimos críticos del momento como Alejandro Miquis, José Alsina, Antonio Asenjo; publicación de obras teatrales de escritores de la época, destacando por su influjo Jacinto Benavente; un apartado final sobre el cotilleo que este mundo del teatro, tan particular, lleva consigo. Y por último, una sección encabezada por el epígrafe «Las mujeres del teatro", donde apareció el poema La bella Lucerito de Pérez de Ayala; colaboraron asimismo en este apartado, prolíficamente, Julio Hoyos, González Pastor y Emilio Carrere.

Igual que ocurre con la colección de El álbum Ibero-americano, la de Comedias y comediantes se encuentra (después de haber compro- 
bado las existentes en la Biblioteca Nacional de Madrid y la Hemeroteca Municipal de Madrid) mutilada, aunque se compensan entre las $\operatorname{dos}^{44}$.

A) La mandolinata está formada por cincuenta y seis versos, distribuidos en catorce cuartetos, cuyos versos, dodecasílabos, riman en consonante $\mathrm{ABAB}$. Es, sin lugar a dudas, la elevación de la forma métrica, tan patente en el modernismo, o como Navarro Tomás afirma en su ejemplar obra:

La armonía de vocablos, acentos, sonidos y rimas entraba en el propósito renovador que aspiraba juntamente a la depuración y enriquecimiento del verso, de los temas y del lenguaje poético ${ }^{45}$.

La mejor definición de este texto es la belleza del contenido, por lo surreal e idealista. Seis personajes, que son seis idílicas imágenes femeninas, contienen en sus gracias y movimientos el embrujo de una sensualidad espiritualizada, acorde con el perfecto trazado formal que este texto presenta, mas no con vaciedad sino, al contrario, con sugerencias musicales y elegancia léxica unidas a un ritmo austero. La riqueza ornamental no sólo se advierte en la ejecución métrico-formal, sino en el vocabulario rico y copioso tan característico en el maestro Pérez de Ayala:

44. En los últimos años han aparecido trabajos de recuperación de textos de Ramón Pérez de Ayala, en su mayoría presentando nuevos poemas, por supuesto y por desgracia no todos los que quisiésemos. Macklin, tras su investigación en las revistas del Modernismo, manejó la publicación La revista ibérica hallando en ella dos publicaciones: el artículo "Stuart Merrill (esbozo impresionista)», junto a una traducción del propio Pérez de Ayala de los «Poemas de crepúsculo» de Stuart Merrill; y un poema titulado "Ofrenda». El artículo y la traducción aparecieron el 15.07.1902, el poema el 20.08.1902. Este trabajo se publicó en el B.I.E.A., n. ${ }^{\circ}$ 107, septiembrediciembre 1982, pp. 683-689.

Ricardo Senabre publicó en Insula "La prehistoria poética de Pérez de Ayala» en el n. ${ }^{\circ} 346$, septiembre 1975; donde presenta el poema Malhumoradas, exhumado del semanario Nuevo mundo, n. ${ }^{\circ} 527,11.02 .1904$. En este articulo nos dice Senabre que "La poesía de Pérez de Ayala, en cambio, ha sido, en general, menos estudiada, aunque en los últimos años ha suscitado algún trabajo de interés».

Por su parte Manuel Fernández Avello nos presentó tres nuevos textos poéticos en "Versos inéditos de Pérez de Ayala: un dezir y dos layes en honor de su prima Josefina», B.I.E.A., n. ${ }^{\circ} 115$, mayo-agosto 1985 , pp. 587-598.

45. Navarro Tomás, Tomás, Métrica española, séptima edición, Edit. Labor, Barcelona, 1986, p. 399. 


\section{LA MANDOLINATA ${ }^{46}$}

Sobre las ebúrneas gradas bizantinas, entre rasos ricos y piedras preciosas, van las seis princesas, en sus mandolinas modulando gráciles frases amorosas.

Son las seis princesas de un país distante de que hablan las áureas crónicas francesas; de un país en donde la brisa galante suspiros murmura, son las seis princesas.

Amalia: corona la regia figura las líneas correctas de su rostro fino, de Bizancio finge débil escultura o frágil madona del buen Perusino.

Paz: lo austero tiene de una diosa ática que esculpiera Fidias en mármol pentélico, y surge en sus ojos atracción simpática que esfuma en el ánimo propósito bélico.

Victoria es capullo de tibia fragancia que a un beso temprano de amor se entreabrió; luce de las reinas la misma elegancia que, a un tiempo, en Versalles, pintaba Watteau.

Es suave y de brisa la risa de Luisa, aroma y conjura los besos soñados cuando la princesa deslíe su risa que finge por entre los dientes nevados.

María: sus ojos son de terciopelo, ojos que destellan en tenues cambiantes. Luce rosas ígneas sobre el negro pelo; tal en sus gitanas Miguel de Cervantes.

Y Ana, en cuyo rostro no es blanca la nieve, un ángel ha hilado su cabello en oro; de su cuerpo lindo la escultura es leve y en sus labios arde de amor un tesoro.

Sonríen las rosas pomposas y hermosas - las mejillas rosas son en las princesasy las mandolinas dicen quejumbrosas secretos que ocultan las bocas traviesas.

El crin crin armónico tiene indiscreciones y al azul lanzando sus notas perladas el ritmo modula de los corazones y rima destellos de amantes miradas.

46. Obsérvese el paralelismo existente con "Sonetos en el gusto francés", en Helios, n." 1, abril de 1903; a diferencia, estos están versados en octosílabos y se caracterizan por su agilidad, siendo aquellos más mayestáticos. 
De los recios trajes entre brocateles cual pálido lirio florece la mano; tal trazó sus vírgenes con suaves pinceles en sus cuadros místicos el viejo Tiziano.

El plectro de Concha destaca en la cuerda, la mano de nieve nostalgias evoca y la vacilante música se acuerda al leve y discreto temblor de una boca.

Hablan indiscretas las seis mandolinas de las seis princesas de los labios rojos; hablan los secretos de las bocas finas, de los pechos frágiles, de los negros ojos.

$Y$ entre el torbellino de las notas locas que brillan con giros mágicos de plata, tienen languideces de dolor las notas que va sollozando la mandolinata.

B) La diosa locura posee gran similitud formal con el texto ante rior: la belleza de las imágenes que provoca el lenguaje tan colorista, rítmico e indeleblemente estilizado, propio y fruto de una imaginación tan copiosamente clarividente. El poema es una crítica al mundo elegante madrileño, tan bellamente estampado que parecen adquirir movimientos reales sus personajes; ofreciéndonos en un cuadro tan común en la época nuevas sensaciones, percepciones y un fino humorismo e ironía, anticipo estilístico de su caracteristica original en la narrativa: lo grotesco. A este respecto, nada mejor que aplicarle al autor asturiano unas frases por él escritas:

Un artista es un hombre que ha consagrado su vida a ver las cosas por primera vez ${ }^{47}$.

Y para ello ha de servirse de «el orfebre más sutil y que nunca tuvo ni tendrá quien lo emule...: la imaginación ${ }^{48}$.

El texto se compone, también, de cincuenta y seis versos, asimismo dodecasílabos. El poema está dedicado al Marqués de Valero de Urría. Hasta el momento se conocían dos trabajos también dedicados a dicha persona: "Carta particular» y "En el homenaje al Marqués de Valero de Urría» ${ }^{49}$. Sobre él nos comenta el biógrafo Jesús Andrés So-

47. Pérez de Ayala, Ramón, Tabla rasa, edit. Bullón, Madrid, 1963, p. 219.

48. Pérez de Ayala, Ramón, Pequeños ensayos, Biblioteca nueva, Madrid, 1963, p. 75.

49. «Carta particular» está publicado en Obras completas, tomo II, pp. 19 y 20 , fechado en el año de 1903. «En el homenaje al Marqués de Valero de Urría»-según consta en 
lís que «en la época en la que Pérez de Ayala frecuentaba el Casino de Oviedo era su presidente el Marqués de Valero de Urría ${ }^{50}$, quien descubrió en nuestro creador "su disposición para la literatura y la poesía y fue su orientador en ambas" ${ }^{51}$.

\section{LA DIOSA LOCURA... Estudio al pastel}

\section{Al Marqués de Valero de Urría}

La diosa locura de risas perladas -risas en que perlas desgrana riente encendiendo bocas con las llamaradas de goces futuros, flota en el ambiente.

Penden en los muros tapices rojizos, cubre el pavimento alfombra escarlata, y en los artesones lucen sus hechizos helénicos rostros de efebos de plata. Los rígidos pliegues de las colgaduras simulan solemnes, litúrgicos mantos; doquiera, soportan níveas esculturas ménsulas corintias de áureos acantos. Esbeltas arañas de oro cincelado engarzan diamantes de luz refulgentes, y en un fino auténtico Palyssi esmaltado las rosas de sangre yacen indolentes. Dulces violoncelos y tristes violas sollozan cadencias de un vals delirante, y con blando impulso se mueven las olas etéreas, polícromas del mundo elegante. Aquí, una Ateniense de húmedas miradas ostenta sus hombros para muchos caros -se ven en sus formas tibias y rosadas los tintes de nácar de mármol de Parosy entre los sollozos de los violines escucha imposible, bella, escultural, los dulces requiebros de los paladines, uno florentino y otro provenzal.

Allá, una Teodora beldad bizantina que lleva en sus ojos el Bósforo azul con suave y lasciva molicie se inclina ciñendo su clámide de raso de tul:

la obra de García de la Concha: Los senderos poéticos de Ramón Pérez de Ayala, Archivum, 1970 , p. 30- fue un ofrecimiento con motivo de un homenaje al Marqués, el 24 de febrero de 1907.

50. Solís, J.A., Vida de Ramón Pérez de Ayala, Candás, 1979, p. 34.

51. Ibid, p. 35. 
su risa engañosa de mágicos giros seduce a un esbelto, gentil chambelán, cuya ardiente súplica y tiernos suspiros envueltos en notas de la orquesta van. Pasea una Médicis maligna, enigmática, que enlaza su brazo a un Conde español, una hija del Nilo de expresión hierática contempla a sus plantas rendido al rey sol. De un lado una dama de ojos esmeralda su busto recuesta en muelle cojin, mientras, misterioso murmura a su espalda sentidas endechas un rubio Delfín; de otro, un atrevido paje veneciano con un cisne blanco en campo de azur sus cálidos besos estampa en la mano menuda y sedosa de una Pompadour. El vals dice lento frases voluptuosas, $y$ vense en el fondo entre medias tintas gentiles galanes, mujeres hermosas, y joyas, y sedas, y tules y cintas.

La Diosa Locura de risas perladas -risas en que perlas desgrana rienteencendiendo bocas con las llamaradas de goces futuros reina en el ambiente.

C) La bella Lucerito se publicó en 1911, en él el verso ya no transcurre equilibrado, con la majestuosidad del dodecasílabo, sino resquebrajado, inquieto, en plena alteración como los pasos y ademanes gesticulantes de las actrices en el espectáculo. Consta de treinta y siete versos: un quinteto de gran originalidad por el emplazamiento del heptasílabo respecto a los endecasílabos: 7a 11B 11B 11A 11A y ocho cuartetos entre los cuales el verso fluctúa entre el heptasílabo en combinación con el endecasílabo, el eneasílabo y en mínima cuantía el dodecasílabo y alejandrino.

\section{LA BELLA LUCERITO}

\section{(Esbozo de sentimientos que provoca la danza)}

¿Bien, chavita, Lolita, Argentinita, Malaguita, todas las que habéis celebrado vuestras bodas con el monstruo voraz que goza y grita y os desea, y al cabo os marchita!

Vuestra flor al esposo vigor da; por su amor teje danzas vuestro pie; vuestros ojos se encienden ¡anda ya!; el rojo labio es para el beso ¡olé! 
¡Con qué dúctil dulzura y sumisión, aurora de un futuro próximo, doblegáis vuestra cintura, hecha para el supremo abrazo impuro!

¿Con cuánta gentileza enderezáis al aire los amenos senos: una realeza marmórea, y por la vida hechidos, llenos!

¡Cuán sutiles y apenas grávidas! El cabello, endrina o miel. A la boca febril brindan las venas un arroyuelo azul sobre la piel.

¡Y vosotras, adolescentes de muslo fino y acerado, que por ser sonrientes e inconscientes placéis al amor hastiado!

Son vuestros brazos infantiles como un árbol mozo y en flor que moviera brisas gentiles de juventud y un gran frescor.

$\mathrm{Y}$ vosotras, tan placenteras y raudas, como Salomé, o tristes, como bayaderas, o vertiginosas jolé!

A todas os admiro, ingenuas criaturas, ya que en la vida todo baila sin ton ni son, y sólo hacéis vosotras ritmos y galanuras con pie tan breve como es vuestro corazón. 